\title{
Philanthropic Fund Raising for Higher Education
}

\author{
A.S.M.A. Haseeb ${ }^{1,2, *}$ \\ ${ }^{1}$ Innovative Industry and Sustainability Science Research Cluster, University of Malaya, \\ 50603 Kuala Lumpur, Malaysia \\ ${ }^{2}$ Department of Mechanical Engineering, University of Malaya, 50603 Kuala Lumpur, Malaysia
}

\section{"Corresponding author email: \\ haseeb@um.edu.my}

Received date: 23 May 2018 Published date: 31 Dec 2018

How to cite:

Haseeb, A. (2018). Fund Raising for Higher Education. Journal of Research Management \& Governance, 1(1), 44-50. Retrieved from https:// ejournal.um.edu.my/index.php/ JRMG/article/view/11869

DOI:

https://doi.org/10.22452/ jrmg.vol1no1.4

\begin{abstract}
With the recent trend towards mass higher education, funding for higher education has become an important issue around the globe. Many governments do not seem to be able to afford it. Economic crisis from time to time makes the situation even worse. Fundraising by universities from alternative sources is increasingly being discussed. This article intends to give an introduction to philanthropic fundraising for higher education and research. Early history of fundraising for higher education and fundraising scenarios in the US, UK and EU are presented. Different models of university fundraising is outlined. Some thoughts on the potential of university fundraising in the Malaysian context are presented towards the end.
\end{abstract}

Keywords: philanthropic fundraising; fundraising models; higher education; fundraising history; Malaysian scenario

\section{INTRODUCTION}

An increasing fraction of the population across the globe is receiving university education nowadays. Traditionally, in majority of the countries, higher education has been mainly funded by the government. However, with the recent trend towards mass higher education, many governments are finding it increasingly difficult to fully fund university education. Over the years, higher education sector has been the victim of budget cuts in times of financial crisis. This has put universities in a vulnerable situation.

There has been an increasing expectation worldwide that universities should raise funds from alternative sources. Public universities in Malaysia have also been asked to raise funds on their own to meet a part of their expenditure. This has become an important issue for higher education leaders in the country. This article intends to give an introduction to fundraising for higher education and research. Early history of fundraising is presented in the next section which is followed by fundraising scenarios in the US, UK and EU. A summary of the different models of university fundraising is then provided. Following this, some thoughts on Malaysian scenario are briefly discussed.

\section{EARLY HISTORY OF GIVING TO THE CAUSE OF HIGHER EDUCATION}

The history of fundraising for higher education probably dates back as early as 387 BC when Plato established the Academy in Athens. The Academy was established through contributions, which included land endowment, by Plato himself, and Cimon, an Athenian statesman and military leader. The endowment generated income to sustain the Academy which operated for the next nine hundred years 
(Cook \& Lasher, 1996). Another example of philanthropic funding for higher education is associated with the University of Al-Qarawiyyin, which is in Fez, Morocco. The university is considered to be the oldest continually operating first degree-awarding educational institution in the world (University of AlQuaraouiyine; UNESCO). The donation from Fatima al-Fihri, the daughter of a wealthy merchant Mohammed al-Fihri, made it possible to establish this higher education institution in 859. In more recent time, the history of giving to the cause of higher education is associated with the Harvard College (established in 1636), which eventually grew into the Harvard University. A young clergyman, John Harvard, donated half of his estate and his personal library to the college. His monetary contribution allowed the college to send a delegation to England in 1643 to gain additional financial support for the college (Harvard University). Here is an excerpt from what can probably be considered as the first fundraising brochure for higher education (The Economist, 2015):

"After God had carried us safe to New England, and we had builded our houses, provide necessaries for our livelihood, reared convenient places for God's worship and settled Civil Government, one of the next things we longed for and looked for was to advance learning and perpetuate it to posterity."

Philanthropic fundraising for the cause of higher education continues to gain more and more importance. It has been proven to be very successful in the USA. Universities in other parts of the world are also exploring fundraising as a means to gain financial sustainability. Fundraising scenario in a few country/region is briefly presented in the next section.

\section{UNIVERSITY FUNDRAISING IN DIFFERENT COUNTRIES}

\subsection{The USA}

In the US, fundraising for higher education has a deep-rooted base since its beginning with the establishment of the Harvard College as mentioned above. Fundraising is considered to be a part of the culture in the US where government role is desired to be limited. Citizens are habituated to support these institutions (Times Higher Education, 2009). Giving to the cause of higher education can be related to a bigger culture of philanthropy in the US. In 2016, the total of philanthropic giving in the US amounted to USD 390 billion (The Giving Institute, 2017) which is $2.11 \%$ of the US GDP. Religious organizations received the highest, USD 119 billion (32\%) from philanthropy. The higher education sector raised USD 41 billion in 2016. Out of this amount, USD 17.45 billion (42.50\%) came from alumni and non-alumni individuals, while different foundations donated USD 12.45 billion. Corporations' donations to higher education amounted to USD 6.60 billion (Council for Aid to Education, 2016). A bulk of the philanthropic grants given to the US higher education sector is attracted by the top few universities, for example, Harvard, Stanford etc. The top $1 \%$ of US universities raised $27 \%$ of all donations to higher education.

Fundraising, as a profession, is quite well established in the US. Universities offer academic courses and degree programmes to train professionals specialized in fundraising (Erwin, 2011). Fundraising emerged as an academic sub-discipline there. Graduate level research is carried out on fundraising for higher education (Satterwhite, 2004; Caboni, 2010; Walcott, 2015; Garland, 2013; Proper, 2011; Carver, 2014).

A lot of efforts go into developing the profession of fundraising. A few of the famous professional organizations in this area include the Council for Advancement and Support of Education (CASE) and Council for Aid to Education (CAE). CASE is a large organization and has established itself beyond the shore of the US. It has 3670 member universities, colleges and schools in 82 countries (Advancement and Support of Education). It is the largest of its kind in the world with its offices in London, Washington 
DC and Singapore. CASE provides professional support service and training, administers award for outstanding practice, publishes books, provides tools and engages in advocacy.

In the US universities, fundraising is considered to be a critical management function, similar to that in a non-profit organization (Erwin, 2011). University presidents in the US generally play the central role in fundraising. In fact, fund raising effectiveness is very often considered as an important factor in the selection of presidents and as an indicator of their success. Presidents provide the administrative leadership and mainly focus on big donors. He/she is, of course, supported by team efforts of all, including fundraising officers, administrators and faculty members (Satterwhite, 2004; Cook, 1994).

\subsection{The UK}

The UK used to have the tradition of voluntary support for higher education in the early period (Proper, 2009). But in the twentieth century, higher education in the UK has mainly been supported by the government. In recent years, however, declining support from the government has forced the universities to resort to fundraising efforts. The higher education sector in the UK has been putting serious efforts on fundraising for only a decade or so. This is in contrast with the US which has an unbroken history of fundraising for centuries. The quantum of fund raised in the UK for higher education is obviously lower compared with that in the US. Oxford and Cambridge Universities are the largest recipients of funds with each receiving between $f 200 m$ - $f 250 m$ per year (Thomas, 2016).

Fund raising does not happen automatically. Universities have to put considerable efforts, invest adequately and hire well trained human resources for raising funds. In the UK, a survey shows that universities spent $£ 55$ million on fundraising in 2006-07, and each university employed an average of ten staff to do the job (Times Higher Education, 2009). One of the main challenges that the UK universities currently face in fundraising is a serious lack of qualified fundraising professionals. It is estimated that the need for fundraising staff will double or even triple by 2020 (Gallagher, 2014). The UK universities have been increasingly looking to recruit fundraising professionals from the US and Canada, which have a more mature fundraising sector.

\subsection{The EU}

The EU as well is paying attention to fundraising for higher education in recent time (European Commission, 2006; European Commission, 2008; European Commission, 2011; Pérez-Esparrells, \& Torre, 2012). In the past, fundraising was not taken seriously by universities in the EU countries as they were traditionally supported by the respective governments. Citizens normally have expectation of high public spending for education and research, as they pay higher taxes. In general, philanthropic giving in the EU countries is also lower compared with that in the US. But the EU nowadays recognizes that universities should engage in fundraising rather than depending solely on the government. The EU is asking member governments to play their roles in terms of improving the public policy and in developing the culture of giving. The EU is also urging the universities to develop the culture of asking (European Commission, 2011; Pérez-Esparrells, \& Torre, 2012). Some of the main difficulties of fundraising in Europe include lack of philanthropic spirit, tax incentives, and institutional fundraising infrastructure (Mora \& Nugent, 1998). The EU came up with a set of ten recommendations to facilitate fundraising by universities (European Commission, 2008):

1. Universities should include fundraising from philanthropy as part of their overall strategy.

2. Build up internal fundraising competences within universities. 
3. Review the qualifications required of university leadership to include fundraising skills and make fundraising one of their core responsibilities.

4. Review management and accounting practices at universities.

5. Take advantage of increased university autonomy.

6. Explore possibilities for the creation of university foundations.

7. Introduce a system of 'matching funds' by government for donations raised from private donors.

8. Review fiscal rules to make them more inviting to university research fundraising.

9. Claim the 'right of philanthropic transfer' within the EU.

10. Promote a culture of giving and create a culture of asking.

These recommendations take into account the fact that fundraising for higher education is not something that universities can tackle alone. Both governments and policy makers have important roles to play.

\section{FUNDRAISING MODELS}

There are different ways a university can raise funds. University fundraising efforts have been categorized into four major models (European Commission, 2008):

1) Alumni Model, 2) Major Gift Model, 3) Foundation Research Model, and 4) Multi-Mode Model.

The Alumni Model is characterized by a continuous collection of small donation by the alumni relationship office of a university. Such an office is also called an institutional advancement office or a development office. Interactions with potential donors are usually structured but informal, and include mass mailings of standard letters, e-mails etc. In the Major Gift Mode, universities attract donations from wealthy individuals. Such donations are larger than those targeted by other models and their use is usually specified by the donors. University leadership including the president plays the main role in connecting and creating personal relationship with these wealthy individuals. In the Foundation Model, individual researchers apply for research grants to different public and private funding bodies for research. The main actors in this model are individual researchers. In the Multi-Mode Model, more than one models are combined to raise fund.

It may be noted in this connection that Waqf, a pious endowment in the Islamic tradition, can be an effective mechanism to raise funds for higher education (Mahamood \& Rahman, 2015; Koç, 2012). The use of Waqf in higher education is quite well established in Turkey, where 75 out of a total of 195 universities are substantially funded through Waqf (Razak et al., 2016). A couple of universities in Indonesia are also fully funded through Waqf. Some universities in Malaysia established their Waqf funds and so far raised a small amount of money (Razak et al., 2016). This avenue deserves to be further explored on a wider scale.

\section{MALAYSIAN SCENARIO}

Different public universities in Malaysia are currently generating some funds on their own. But the amount raised is meagre at present. University authorities are struggling with raising a substantial amount to make them financially sustainable in the long run.

In order to analyse the potential of fundraising for higher education in Malaysia, let us assume that the amount raised for higher education is correlated with the giving tendency of the citizens of a nation. The Charities Aid Foundation has developed the World Giving Index which measures the propensity of the population of a country to give charity (Charities Aid Foundation, 2016). The World Giving Index is 
measured by the average of the following three factors: 1) percentage of population giving money to charities, 2) percentage of the population who have volunteered for an organisation in the previous month, and 3) percentage of the population who have helped a stranger in the previous month. The sum of these three quantities divided by three gives the World Giving Index. According to the Global Giving Index, Malaysia's position is $22^{\text {nd }}$ out of a total 140 countries surveyed (Charities Aid Foundation, 2016). This can be considered as encouraging. Detailed data on the giving habits of Malaysians are not available though. Limited number of studies shows that $71.8 \%$ of Malaysians would like to contribute to religious causes, while 23.9\% would like to donate to education (Rohayati et al., 2016; Bustamy et al., 2002).

One can do a back-of-the-envelope calculation regarding how much money can possibly be raised for higher education in Malaysia. As mentioned earlier, charity in the US accounts for $2.11 \%$ of GDP. In the $E U$, it varies from country to country: the range can be between $0.1-0.8 \%$ of GDP. The average in $\mathrm{EU}$ is $0.2 \%$ of GDP for nine countries (Observatoire de la Fondation de France / CERPhi, 2015). In the absence of any such data for Malaysia, let us assume that philanthropic giving in Malaysia is in the lower side of the EU range and is approximately $0.1-0.5 \%$ of GDP. Assuming that $15 \%$ of this amount can be attracted to the cause of higher education, universities in Malaysia have the potential to raise between RM186 to 932 million every year (calculated based on the GDP of 2017). This is just an indicative amount and by no means accurate. Research needs to be carried out to make more accurate estimates.

The above amount may not be very large compared with the operating budget of twenty public universities, which is RM6.72 billion in 2018. The amount turns out to be between about $3-14 \%$ of the operating budget. Even to raise this amount, it will be important at this stage to create an effective ecosystem for fundraising for higher education in the country. Facilitation by the government, civil society and other stakeholders can go a long way in promoting the culture of giving to the cause of higher education. Universities themselves need to create the internal infrastructure, engage in capacity building, invest and employ trained professionals to help with fundraising.

\section{CONCLUSION}

Recent trend towards mass higher education is making it increasingly difficult for governments to fully fund university education. As a result, fundraising by universities has become an important issue in many parts of the world. Fundraising for higher education is quite mature in the US, which has an unbroken tradition for centuries. The success of university fundraising in the US is thought to be related to the greater culture of philanthropy and the desire for limited role of government. The UK universities, in recent decades, are working seriously on fundraising as government support for higher education is dwindling. The UK universities are mainly adapting the US fundraising model. The EU is also encouraging the governments and universities in member countries to develop fundraising for higher education and research. There are four major models of university fundraising: Alumni Model, 2) Major Gift Model, 3) Foundation Research Model, and 4) Multi-Mode Model. In addition, Waqf, a pious donation in the Islamic tradition, has been found to be successful in some Islamic countries, e.g. Turkey. Universities in Malaysia have reasonable potential to raise funds. To be successful, universities need to create internal infrastructure, engage in capacity building, invest and employ trained professionals. However, the success will not depend only on universities. It will require the development of a culture of giving to the cause of higher education where government, policy makers, civil society and other stakeholders have big roles to play. 


\section{REFERENCES}

Advancement and Support of Education. Retrieved from https://www.case.org

Bustamy, R., Fernandez, J.M., Ibrahim, A.R., Cheah, A.S.M., \& Nadarajah, M. (2002). Practices of individual giving in Penang. In A Giving Society? In J.M. Fernandez \& A.R. Ibrahim (Eds), The State of Philanthropy in Malaysia (pp. 237-276). Penang: Penerbit Universiti Sains Malaysia.

Caboni, T. C. (2010). The normative structure of college and university fundraising behaviors. The Journal of Higher Education, 81(3), 339-365.

Carver, J. M. (2014). Tensions and metaphors in higher education fundraising profession. (Master's Thesis). Western Kentucky University.

Charities Aid Foundation. (2016). CAF World Giving Index 2016. Retrieved from https:// www.cafonline.org/docs/default-source/about-us-

publications/1950a_wgi_2016_report_web_v2_241016.pdf

Cook, W. B. (1994). Courting philanthropy: The role of university presidents and chancellors in fundraising. (PhD dissertation). The University of Texas at Austin.

Cook, W. B., \& Lasher, W. H. (1996) Toward a theory of fund raising in higher education. Review of Higher Education, 20, 33-51.

Council for Aid to Education, USA (2016), Colleges and universities raise \$41 billion in 2016, Retrieved from http://cae.org/images/uploads/pdf/VSE-2016-Press-Release.pdf

Erwin, C. O. (2011, Mar). How is fundraising being taught in colleges and universities? Looking for evidence of a professional competency-based approach. Paper presented the annual meeting of the Alabama Political Science Association, Auburn, Alabama.

European Commission. (2006). Giving more for research.

European Commission. (2008). Fundraising by universities from philanthropic sources: developing partnerships between universities and private donors.

European Commission. (2011). Giving in evidence: Fundraising from philanthropy in European universities.

Gallagher, P. (2014, July 27). Universities Resort to Cold-Calling Ex-Students. The Independent. Retrieved from http://www.independent.co.uk/student/news/universities-resortto-cold-calling-ex-students-9631861.html

Garland, J. P. (2013). Membership-based fundraising within higher education: A strategic marketing management perspective. (Master's Thesis). Louisiana State University.

Harvard University. Historical facts. Retrieved from https://www.harvard.edu/about-harvard/harvardglance/history/historical-facts

Koç, M. (2012, October). Foundation (Awqaf) universities in Turkey---past, present and future. Paper presented at 3rd International Conference on Islam and Higher Education (ICIHE 2012), Kuantan, Malaysia.

Mahamood, S. M. \&Rahman, A. A. (2015). Financing universities through waqf, pious endowment: is it possible? Humanomics, 31(4), .430-453.

Mora, J-G.\& Nugent, M. (1998). Seeking new resources for European universities: the example of fundraising in the U.S. European Journal of Education, 33, 1.

Observatoire de la Fondation de France / CERPhi, France (2015). An overview of philanthropy in Europe.

Pérez-Esparrells, C. and Torre, E. M. (2012). The challenge of fundraising in universities in Europe. International Journal of Higher Education, 1(2), 55-66.

Proper, E. (2009). Bringing educational fundraising back to Great Britain: A comparison with the United States. Journal of Higher Education Policy and Management, 31(2),149-159. 
Proper, E. (2011). The outcomes of board involvement in fundraising at independent four-year colleges: An organizational theory perspective. (PhD Dissertation). Vanderbilt University.

Razak, D. A., Embi, N. A. C., Salleh M. C. M. \& Fakhrunnas, F. (2016). A study on sources of waqf funds for higher education in selected countries, Adam Akademi, 6(1), 113-128.

Rohayati, M. I., Najdi, Y., \& Williamson, J. C. (2016). Review philanthropic fundraising of higher education institutions: A review of the Malaysian and Australian perspectives. Sustainability, 8, 541.doi:10.3390/su8060541

Satterwhite, C. R. (2004). The function of university presidents and CEO's in fundraising: A study of public universities with capital campaign less that $\$ 100$ million. (Doctor of Education Dissertation). Texas Tech University.

The Economist. (2015, March 26). The world is going to university. Retrieved from http:// www.economist.com/news/leaders/21647285-more-and-more-money-being-spent-highereducation-too-little-known-about-whether-it

The Giving Institute. (2017). Giving USA 2017: The annual report on philanthropy for the year 2016. USA.

Thomas, E. (2016, March 30). Fundraising brings universities more than just money. Here's how to do it well. The Guardian. Retrieved from https://www.theguardian.com/higher-educationnetwork/2016/mar/30/fundraising-brings-universities-more-than-just-money-heres-how-to-do-itwell

Times Higher Education. (2009, August 06). Fundraising: How to get alumni cough up. Retrieved from https://www.timeshighereducation.com/features/fundraising-how-to-get-alumni-to-coughup/407627.article

UNESCO. Medina of Fez. Retrieved from http://whc.unesco.org/en/list/170 University of Al Quaraouiyine. Retrieved from https://en.wikipedia.org/wiki/University_of_Al_Quaraouiyine

Walcott, M. E. (2015). Predictive modelling and alumni fundraising in higher education. (PhD Dissertation). Illinois State University. 